\title{
Should Gambling Markets be Privatized? An Examination of State Lotteries in the United States
}

\author{
By
}

Kent Grote and Victor Matheson

May 2013

\section{COLLEGE OF THE HOLY CROSS, DEPARTMENT OF ECONOMICS \\ FACULTY RESEARCH SERIES, PAPER NO. 13-03*}

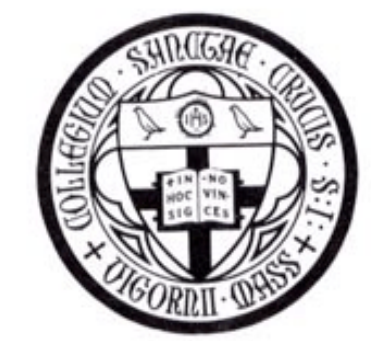

Department of Economics

College of the Holy Cross

Box 45A

Worcester, Massachusetts 01610

(508) 793-3362 (phone)

(508) 793-3708 (fax)

http://www.holycross.edu/departments/economics/website

*All papers in the Holy Cross Working Paper Series should be considered draft versions subject to future revision. Comments and suggestions are welcome. 


\title{
Should Gambling Markets be Privatized? An Examination of State Lotteries in the United States
}

\author{
By \\ Kent Grote ${ }^{\dagger}$ \\ College of the Holy Cross \\ and \\ Victor Matheson ${ }^{\dagger \dagger}$ \\ College of the Holy Cross
}

May 2013

\begin{abstract}
State lotteries currently operate in 43 states across the US. Recently, three states have privatized their lottery operations, handing over the management of their lotteries to private companies in hopes of generating greater revenues for the state governments. Questions arise regarding the economic rationale for this decision and an economic model is presented to determine whether one state, Illinois, has been successful at generating more state transfer revenues as a result of privatization in its first year of results. The issue of lottery privatization is also examined in the larger context of overall growth in the gambling industry in the United States with particular attention paid to sports gambling.
\end{abstract}

JEL Classification Codes: K35, H71, L83

Keywords: lotto, lottery, public finance, gambling

${ }^{\dagger}$ Department of Economics and Business, Lake Forest College, Lake Forest, IL 60045, 847-735-5196 (phone), 847-735-6193 (fax), grote@lfc.edu

${ }^{\dagger}$ Department of Economics, Box 157A, College of the Holy Cross, Worcester, MA 01610-2395, 508-793-2649 (phone), 508-793-3710 (fax), vmatheso@ holycross.edu 


\section{Introduction to Lotteries in the US}

Since 1964, when New Hampshire became the first state to offer a state-run lottery in the $20^{\text {th }}$ century, lotteries have become commonplace around the US. As of 2013, 43 states and the District of Columbia offered lotteries and these games have become a small but important component of state revenues. In 2011, state lotteries generated more than $\$ 18$ billion for state governments, representing $1.7 \%$ of all government revenues generated by states excluding transfers from the federal government (Humphreys and Matheson, 2013).

Early in American history, lotteries were quite common but also were generally operated by private organizations, not by state governments. For example, the construction and expansion of many early private American universities, including Harvard and Princeton, were financed in part through lottery sales. Prominent American leaders also lent their support to lotteries designed to raise funds for public works. John Hancock's signature appears on lottery tickets sold to fund the construction of Faneuil Hall while George Washington administered the unsuccessful 1768 Mountain Road Lottery in Virginia, and Ben Franklin organized a lottery during the American Revolution to finance the purchase of cannons to aid in the defense of Philadelphia (Matheson and Grote, 2008).

While the organization and operation of lotteries in early America was generally undertaken by private individuals and groups, governments still had a role in authorizing lotteries. For example, in 1612 King James I of England issued a royal decree authorizing the Virginia Company to create a lottery to provide funds for Jamestown, the first English colony in America. Between 1612 and 1621, the company raised 29,000 pounds sterling to support the colony (Jamestown-Yorktown Foundation, 2013). Indeed, the rules regarding the authorization of lotteries were an issue of contention in the lead-up to the Revolutionary War when, in 1769, 
the British crown attempted to prevent the sale of lottery tickets by groups or individuals that had not received royal permission (Dunstan, 1997).

Lotteries began to fall out of favor in the early 1800s as governments developed alternative methods of generating revenue, moral objections to lotteries began to rise, and concern about fraud in privately run lotteries increased. New York became the first state to ban new games in 1821 when its constitution was amended to prohibit lotteries not otherwise “previously provided for by law.” (Benjamin, 2013) In 1833, New York ended lotteries completely and was joined in its prohibition by Pennsylvania and Massachusetts. Within just a few years most states had stopped authorizing lotteries, and by 1860 only Delaware, Kentucky, and Missouri still allowed these games of chance (Dunstan, 1997).

Lotteries returned after the American Civil War as states in the South desperately searched for new sources of revenue during Reconstruction. These lotteries were generally shortlived with one very notable exception. The last existing lottery of the $19^{\text {th }}$ century was run by the Louisiana State Lottery Company, a private firm granted a 25 -year charter in 1868 by the Louisiana state legislature in exchange for a $\$ 40,000$ annual payment to the state. The legislature also banned other organized gambling at the same time, giving the Louisiana State Lottery Company a monopoly on gambling in the state. The company also actively sold tickets around the US, generating over $90 \%$ of its revenue outside of the state of Louisiana, but the company's ability to evade lottery prohibitions in other states came to an end in 1890 when the US Congress banned the interstate transportation of lottery tickets and advertisements, a law whose constitutionality was upheld by the Supreme Court in 1892. The company's charter was not renewed by the state of Louisiana in 1893, despite heavy lobbying by the company that included large bribes offered to members of the state legislature (Louisiana Lottery Corporation, 2013). 
The company then moved its operations to Honduras and continued to illegally sell lottery tickets in the US until its final closure by US law enforcement in 1907.

Lotteries began to return to the US in 1964 when New Hampshire opened the first statesanctioned game of the $20^{\text {th }}$ century. An overwhelming majority of states followed in the subsequent decades with state lotteries spreading to 43 states and the District of Columbia by 2013. State-authorized lotteries in the $20^{\text {th }}$ and $21^{\text {st }}$ century were distinctly different than those of the $19^{\text {th }}$ century, however, in that in all cases the lotteries were directly operated by the state governments themselves. In the $19^{\text {th }}$ century, a "state lottery" was more likely to mean a lottery operated by private individuals but with a state sanction, rather than the modern American meaning of the word where a "state lottery" is essentially a state-owned enterprise under the direct control of the state government and with the state government being the residual claimant of any operating profits. This operational structure has begun to change in the past 2 years in the US as numerous state governments have begun to privatize their lottery operations.

Private operation of public lotteries is nothing new in the rest of the world. Since its beginning in 1994, the UK Lottery has been operated on a for-profit basis by the private company Camelot in exchange for a profit allowance of $0.5 \%$ of gross ticket sales. The Italian Lottery is operated by the private firm Lottomatica.

In the United States, Illinois was the first state to privatize the operations of its lottery when it handed over control to the Northstar Corporation in July 2011. Northstar is a joint venture of Scientific Games, a New York-based manufacturer of lottery tickets and gaming equipment, and GTECH, a wholly owned subsidiary of Lottomatica. Northstar beat out UK rival Camelot in its bid to become the first private company to operate a state lottery in the US. Indiana handed control of its lottery over to GTECH in 2012. In 2013, New Jersey awarded 
operations of its lottery to Northstar NJ, another joint venture of Lottomatica, Scientific Games, and a third venture partner. Pennsylvania agreed in principle to award control of its lottery to Camelot in 2013, as well, but public pressure and internal divisions with the Pennsylvania government scuttled the deal.

\section{Introduction to Casinos in the US}

Throughout much of American history, many taverns and roadhouses permitted card and dice games, but large dedicated casinos were rare. In the early 1800s, the same moral objections that rose against lotteries led to a disapproval of this type of gaming, particularly in the East. By the 1840s, the center of casino gaming had moved to riverboats on the Mississippi River and to New Orleans (Dunstan, 1997). While recreational gambling was generally considered acceptable in the region, professional gamblers and card sharps were looked down upon with severe disfavor.

The American Civil War along with the burgeoning rail system in the country led to the decline of the great riverboats. In their place, casinos began to flourish temporarily in mining boom towns such as San Francisco (1849), Cripple Creek and Central City, Colorado (1859), Virginia City, Nevada (1859), and Deadwood, South Dakota (1874). As miners either moved away when the mines played out or were replaced by more genteel residents that gentrified former mining towns, the "Wild West" atmosphere that encouraged the development of casinos also disappeared. By the turn of the $20^{\text {th }}$ century, casino gaming was again illegal throughout the country. Nevada re-legalized casino gaming in 1931, and it held a nationwide monopoly on the activity (at least legally) until New Jersey introduced casinos to Atlantic City in 1975 (Dunstan, 1997). 
Other states legalized the operation of privately operated casinos over the next three decades although these casinos were generally limited in number or stakes. Often gambling legalization harkened back to the historical roots of gambling in the state. For example, gambling in states along the Mississippi was frequently limited to riverboats, and states with mining heritage opened up former mining towns such as Cripple Creek, Central City, and Deadwood to casinos. As of the end of 2012, 513 commercial casinos operated in 23 states generating $\$ 37.3$ billion in gambling related revenue (American Gaming Association, 2013).

The Seminole Tribe in Florida opened a casino on tribal land offering high stakes bingo in 1979. The state sued to close the facility, but in Seminole Tribe v. Butterworth (1981), the Federal Appeals Court for the region determined that, since the state allowed charitable organizations in the state to offer bingo, it did not have the jurisdiction to prohibit the sovereign government of the Seminole Tribe from offering a similar game even at higher stakes, nor did the state have the right to limit attendance at the Tribe's casino to Tribe members.

The US Supreme Court followed up this decision with its own ruling in California v. Cabazon Band of Mission Indians (1987), which granted Native American Tribes the right to offer gambling options largely free of state control on tribal reservations as long as the state allowed a regulated version of the game to operate elsewhere in the state. Tribal casinos were not permitted to offer games that were criminally prohibited by state law or banned by federal statute.

Given the rise of Indian casinos following these favorable court rulings, the federal government passed the Indian Gaming Regulatory Act of 1988, which provided uniform and formalized gaming rules for Native American reservations across the country. The Act divided gambling activity into three classes. Class I gaming included traditional tribal and social gaming 
for low stakes. Such activity was not subject to regulation from outside of tribal government. Class II gaming included activities where players exclusively played against one another rather than the house such as bingo and poker. Such games were permitted without state regulation if these games were permitted in any fashion elsewhere in the state. Class III gaming included gambling activities where bettors played against the house such as blackjack, slot machines, craps, and roulette. The establishment of an Indian casino with Class III gaming requires a compact with the state in which the tribal reservation is located. As of the end of fiscal year 2011, 421 tribal casinos operated in 28 states generating $\$ 27.2$ billion in gaming revenue (National Indian Gaming Commission, 2012). Between Native American casinos and commercial gaming establishments, 39 states currently offer some form of casino gambling.

\section{Introduction to Pari-mutuel Betting in the US}

Horse racing and other forms of pari-mutuel racing are another form of gambling with a long history in the US. The first horse racing track was laid in 1665 on Long Island in New York, and tracks spread throughout the country with the expansion of the nation. In 1865, parimutuel betting was invented by Pierre Oller, a French perfume shop keeper and rapidly became the standard for horse racing. By the early 1900s, the general anti-gambling ideals of the nation, which led to the decline of legal casinos and lotteries, also eliminated betting at horse tracks everywhere in the country except for Maryland and Kentucky (Nash, 2009). The advent of the Great Depression in the 1930s led to an expansion of many forms of gambling as a form of economic stimulus including horse racing and charitable bingo.

After peaking in the mid-1970s, horse racing has suffered a gradual decline in general interest, at least in part due to the expansion of other types of legalized gambling, including 
lotteries and casinos (Nash, 2009). The total handle wagered on US races totaled $\$ 10.9$ billion in 2012 although net betting revenue is a fraction of this figure (LaMarra, 2013). As of 2012, 78 tracks in 28 states offered thoroughbred racing and 36 tracks in 16 states offered harness racing. Most tracks have a betting window that offers a variety of general pari-mutuel bets. Many tracks also offer simulcast betting on races at other tracks, and 49 tracks in 14 states also offer some type of additional gaming ranging from full service casinos to video lottery terminals or other electronic gaming devices (American Gaming Association, 2013).

\section{Introduction to Sports Gambling in US}

As noted previously, gambling on horse racing has a long history in the US. Betting on other sporting events grew in line with the growth of organized sports in the late 1800s and early 1900s. Indeed, the history of nearly every league in the US goes hand in hand with a story of gambling corruption. Baseball's National League, the forerunner of Major League Baseball and the oldest American professional sports league still in existence, formed in 1876. By 1877, the Louisville Grays ended the season mired in a betting scandal and ceased operation at the end of the year. The Ohio League, a precursor of the National Football League, formed in 1903 as a loose association of American football teams. Just three years later, the Canton Bulldogs Massillon Tigers betting scandal led to the demise of the Canton club and a decline in the popularity of the league. Of course, the 1919 "Black Sox" scandal, where members of the Chicago White Sox were accused of throwing the World Series remains American sports' most famous case of gambling corruption while the 1948 NCAA basketball point shaving incident high-lighted corruption in the college ranks. 
Following the formation of professional leagues, "pool cards," which allowed bettors to gamble on a slate of games, became popular although not generally legal. Following in the footsteps of its casino businesses, Nevada officially legalized sports gambling in 1949, but major casinos didn’t join until Stardust opened a sports book in 1976.

The main impetus that led to the establishment of large, commercial sports books at Nevada casinos was the US elimination of a 10\% tax on sports gambling in 1974. This tax law change led to an increase in sports gambling handle in Nevada from $\$ 825,767$ in 1973 to $\$ 3,873,217$ in 1974 and \$26,170,328 in 1975 (NFL v. Delaware, 1977). Of course, major casinos could not ignore this surge in this particular gambling activity and most followed the lead of the Stardust after 1976. By 2012, over $\$ 3.44$ billion was wagered at 182 sports betting locations throughout the state (UNLV, 2013).

In other states, Montana legalized pool cards beginning in 1974. The Delaware Lottery offered NFL parlay tickets in 1976 and won a court case against the NFL and its allies for the right to offer the game. Nevertheless, the Delaware sports lottery folded after one year because the fixed-odds nature of the tickets couldn't guarantee the statutory tax contribution required under the state's lottery law. The Oregon Lottery offered NFL parlay tickets from 1998-2007 and NBA parley tickets in 1998 and 1999 (although the NBA ticket did not include games featuring the local NBA team, the Portland Trailblazers). The state yielded to pressure from the NCAA in 2007 and terminated its sports lottery in exchange for the NCAA lifting its ban on hosting college basketball tournament games in the state.

With the Professional and Amateur Sports Protection Act of 1992 (PASPA), the federal government banned sports gambling in all states except those with existing legalized sports gaming, which included Nevada, Oregon, Montana, and Delaware. The act bans other lottery 
associations from basing games on sports outcomes, prohibits sports books at casinos outside of these states, and prohibits sports gambling at tribal casinos since the federal government has the ultimate jurisdiction over civil laws on Native American reservations.

Since the passage of PASPA, the Montana Lottery has expanded into sports gambling with the introduction of Fantasy NFL and Fantasy NASCAR games in 2008. It should be noted that these games do not command a high level of player interest, generating weekly handles of just \$2,500 per week for NASCAR and \$5,000 per week for the NFL (Montana Lottery, 2013.) The Delaware Lottery reintroduced NFL parlay lottery tickets 2009 but lost a court case later in the year that would have allowed to the state's lottery association to sell tickets with single game bets. A favorable ruling in the case, in effect, would have allowed the Delaware Lottery to create a fully functional sports book.

Other states have recently begun to challenge PASPA's virtual nationwide ban on sports gaming. New Jersey passed a law that would have allowed sports books at Atlantic City casinos in 2012, but the law was challenged by the major professional sports leagues and the NCAA. Preliminary court rulings have upheld PASPA, denying New Jersey the right to legalize sports gambling, but the state has appealed and the legal process is ongoing as of 2013. Should New Jersey ultimately prevail, it is extremely likely that multiple states, including California, would quickly consider legalizing general sports gambling within their own borders, and multiple state lottery associations could choose to follow Montana and Delaware in offering lottery games based on sports outcomes.

In summary, as of 2013 lotteries and casinos are widespread through the country with most states having legal access to one or both types of gaming. Sports gambling in the US is much more restricted. Only Nevada operates full sports books while lottery associations in 
Montana and Delaware offer limited types of sports gambling. The Oregon Lottery has the right to operate limited sports gambling but has given up their sports lottery operations over a dispute with the NCAA. States are currently challenging the nationwide ban on sports gambling with New Jersey at the forefront. In terms of lottery management, the modern history of lotteries in the US has been that of state operation and management of lotteries, but there has been recent movement towards the privatization of state lotteries. Illinois privatized its lottery in 2011 followed by Indiana in 2012 and New Jersey in 2013. A privatization scheme in Pennsylvania was rejected in 2013. The next section of this paper addresses the questions of whether privatization is an effective method of increasing lottery revenues and whether it should it be encouraged.

\section{Privatization of State Lotteries}

Standard economic theory generally states that free markets lead to optimal allocations of resources, suggesting that government intervention in the marketplace through the control of firms is unlikely to lead to improvements in societal welfare. Furthermore, since government firms do not operate by the same profit incentives that motivate private business owners, there is again concern that state-owned enterprises will fail to achieve the efficiency and productivity of which private firms are capable. On a grand scale, the economic success of western capitalistic nations compared to the economic stagnation experienced by the socialist former Soviet Bloc countries clearly highlighted the efficiency advantages of privately owned firms. The trend around the world over the past several decades has been one of reduced state-ownership of companies. 
Of course, in cases where market failure exists, private firms are less likely to provide optimal outcomes. State-owned enterprises may provide relief in these cases. In many circumstances involving market failures, it is easy to find examples of state-owned enterprises selling goods and services to the public often in direct competition with private pro-profit or private non-profit firms. With respect to public goods, governments often provide public hospitals, parks, and schools. When natural monopolies exist, governments may directly sell goods like municipal water or electricity as opposed to allowing a highly regulated monopoly to exist. When firms sell products with significant negative externalities, government control of the retail establishment may reduce the likelihood of a profit-seeking firm selling more than the societally efficient level of production. For example, liquor stores in many states and cities in the US are government owned. Of course, state ownership is not the only solution to the problem of firms selling products with negative externalities. Most liquor stores in the US are not stateowned enterprises but instead private firms subject to strict government regulation.

With the privatization of lotteries, private firms are granted local monopolies and maximization of revenue may not by societally optimal, particularly with respect to concerns about problem gaming or the distributional impact of government revenue generation. As a case in point, in Camelot's failed bid to win the contract for Illinois' lottery in 2011, the company planned to increase annual per capita lottery ticket sales in the state from \$171 in 2010 to $\$ 292$ in 2016 and in particular to raise annual sales on instant games from $\$ 92$ to $\$ 161$ per person (Illinois Lottery, 2010). While increasing ticket sales is unquestionably good from a revenue generation or profit maximization perspective, there is a real public policy question about raising government revenue in this manner. Given the fact that lottery players are disproportionally poor(especially those who play instant games) encouraging the consumption of a product that, on 
average, makes the poor poorer in order to supplement the incomes of the poor and provide funding for other state programs seems questionable at best

Other questions also exist. Is sufficient innovation possible in the lottery industry to warrant introduction of a middleman who will take a portion of the profits? Privatization often succeeds in increasing profits by cutting costs, but the administrative costs of most state lotteries are only about $5 \%$ of revenues, limiting the efficiency gains that would be possible. Since most of the revenue gains from privatization would come from expanding revenues rather than cutting costs, there is the real question of whether gambling expansion is socially desirable. Often projections of increased revenue are driven by the introduction of video lottery terminals, internet gaming, or expanded advertising, all of which could be done without privatization of the lottery. Finally, it is important to ask whether states can write contracts that prevent privatization of profits when privatized lotteries do well, but socialization of losses when lotteries fail to meet expectations.

\section{Model and Methodology}

In order to test the effect of privatizing a lottery, regression analysis will be performed on state-level data over time to determine the impact of state-level economic and demographic data on the level of transfers that a state lottery generates for the government. Previous contributions to the lottery literature have suggested many demographic and economic variables to explain the level of lottery sales in a state. Selecting from those variables, the current study will use population, income level, and the unemployment rate of a state to explain the level of transfers that a state lottery generates for the state government. Lottery sales and lottery transfers are directly related to one another since more lottery sales will lead to more dollars transferred to the 
government. Because of the direct relationship between the two, it is reasonable to assume that any demographic or economic variables that affect lottery sales would have a similar effect on transfers to the government, even though dollars transferred will be lower than lottery sales due to prize payouts and commissions. Transfers are the preferred variable for the current study because of the prediction that privatization can generate more revenues to the state. The corollary to that prediction is that the revenues transferred should be higher, not that sales dollars are necessarily higher although higher sales are certainly one way to generate more transfers.

There is a rich lottery literature with a variety of contributions that test the impact of demographic and economic variables on lottery sales either within single states or across numerous states. Considering only the variables used in the current model, the empirical results from these studies on population are consistent; however, there are mixed empirical results on unemployment rates and income. A number of studies, including Clotfelter and Cook (1989), Ashley, Liu and Chang (1999) and Frees and Miller (2004) find that population has a positive impact on state lottery sales. Regarding the unemployment rate, Mikesell (1994) and Scott and Garen (1994) both find that a higher unemployment has a positive impact on state lottery sales. However, DeBoer (1990) finds that unemployment rates in New York do not significantly impact lottery sales and Blalock, Just and Simon (2007) find a negative relationship between unemployment rates and sales. Theoretically, one might expect a positive relationship between unemployment rates and lottery sales if lottery sales are regressive in nature and purchased relatively more by people who feel they have few economic alternatives of earning income or wealth in other ways. Blalock, Just and Simon (2007) predict that a positive relationship between unemployment rates and lottery sales is an affirmation of prospect theory, "that individuals become more risk loving when they suffer a financial shock," even though that 
particular study does not support the theory empirically (Blalock, Just and Simon 2007, pp. 560-

1). It may also be that lottery ticket sales are a normal good and, as opportunities to earn income decline due to higher unemployment rates, so, do state lottery sales, predicting a negative relationship between unemployment rates and sales.

The regressive nature of lottery sales along with the question of whether lotteries are normal goods applies equally to the results regarding state income and income per capita on sales and sales per capita in the lottery literature. The general results are that while lottery sales are regressive in nature, implying that lower income households tend to spend a higher percentage of their income on lottery products than higher income households, they also tend to be normal goods, implying that sales dollars increase with higher incomes. ${ }^{1}$ This finding, however, is not consistent across the literature, with some studies finding the opposite results or no impact of income on lottery sales (in dollars or in per capita dollars, depending on the study).

Three different models are proposed and tested, using some combination of the variables previously described. The goal of privatization is to increase revenue transfers from the state's lottery games. Furthermore, tests on both of the dependent variables (change in transfers and change in transfers per capita) indicate that the variables have unit roots. Thus, rather than using transfers or transfers per capita as the dependent variables, the models will use change in transfers and change in transfers per capita as the dependent variables to correct for the unit roots and to emphasize that transfers are expected to increase when the lottery is run by a private firm rather than by a state agency. If individuals in the state are to be made better off through the management by a private firm, then transfer dollars per capita should rise as well.

\footnotetext{
${ }^{1}$ Studies that confirm either or both of these implications include Brinner and Clotfelter (1975), Clotfelter and Cook (1989), Frees and Miller (2004), Blalock, Just and Simon (2007).
} 
The following models are tested empirically:

1) Change in Transfers $i_{i t}=b_{0}+b_{1}$ Change in Income ${ }_{i t}+b_{2}$ Change in Unemployment $_{i t}+$ $b_{3}$ Change in Population ${ }_{i t}+b_{4}$ Privatization Dummy ${ }_{i t}+\alpha_{i}+T_{t}+\varepsilon_{i t}$

2) Change in Transfers ${ }_{i t}=b_{0}+b_{1}$ Change in Income $_{i t}+b_{2}$ Change in Unemployment $_{i t}+$ $b_{3}$ Privatization Dummy ${ }_{i t}+\alpha_{i}+T_{t}+\varepsilon_{i t}$

3) Change in Transfers Per Capita $a_{i t}=b_{0}+b_{1}$ Change in Income Per Capita ${ }_{i t}+b_{2}$ Change in Unemployment $_{i t}+b_{3}$ Privatization Dummy $_{i t}+\alpha_{i}+T_{t}+\varepsilon_{i t}$

Data for the variables represent the time period from 2005 to 2012. Revenue transfers to the state that are generated by the lottery are based on a lottery's fiscal year, which is typically from July to June with data provided by state lottery association websites. Population data is provided by the Annual Estimated Populations Table as of July 1 at the end of each fiscal year for each state, as provided by the U.S. Census Bureau. Personal income data for each state is provided by the Bureau of Economic Analysis and state unemployment rates are provided by the Bureau of Labor Statistics.

The privatization dummy is set equal to one if a state has ceded control of its lottery to a private management firm. Since the data set only includes observations through 2012, in effect, this analysis will only capture the effects of the first year of Illinois privatization. In other words, the number of private state-year observations is only one at time of writing.

It should be noted that the initial year of Northstar's operation of the Illinois Lottery is best described as problematic. The company promised $\$ 851$ million in ticket sales, but only delivered $\$ 757$ million, The company blamed foot-dragging by the state government in their promise to introduce expanded VLT gaming, but the firm was ultimately fined \$20 million for failing to meet its revenue targets. (Garcia 2013) As an aside, the actual revenues generated nearly exactly matched the projections made by Camelot in their failed bid to operate the lottery. 
For each of these equations, initial regressions will be run on the data first without inclusion of state fixed effects $\left(\alpha_{i}\right)$ or time effects $\left(T_{t}\right)$ and then subsequently a second set of regressions will be run including both state fixed effects and time effects. Given the discussion in the previous paragraphs, Change in Income (Per Capita) is expected to have a positive impact on Change in Transfers (Per Capita), based on the assumption that lottery products are normal goods. Change in Unemployment could have either a positive or negative impact on Change in Transfers (Per Capita) depending on whether the regressive nature of lotteries or risky behavior of lower income individuals is more predominant than the nature of lotteries as normal goods. Change in Population is expected to have a positive impact on Change in Transfers as more individuals in a state would provide a larger market for lottery sales. If privatization is successful at generating more income for a state, then the Privatization Dummy should have a positive impact on Change in Transfers (Per Capita).

\section{Results}

Table 1 provides summary statistics for the variables used in the model, while the results of the regression analyses are provided in Tables 2 and 3. Overall, the results reveal that the only variables with a statistically significant impact on the change in transfers of lottery revenue are the change in state income and the change in the unemployment rate. In each of the two regressions without state fixed effects or time effects, change in income has a positive and significant effect on change in transfers, but this same relationship does not hold true on a per capita basis (see Table 3). The coefficients in these two regressions are 0.0006 and 0.0007 , indicating that an added $\$ 100$ dollars of income increases lottery transfers by approximately $\$ 0.06$ to $\$ 0.07$ to the state. The change in the unemployment rate is most consistently 
significant variable, however. In five of the six regression results, the change in unemployment provides a negative and statistically significant coefficient, confirming that lotteries appear to be normal goods, providing declining transfers to state governments as unemployment rates increase. The coefficient on change in unemployment is -3.750 for change in transfers without state fixed effects, between -6.582 and -6.615 for change in transfers with state fixed effects and equal to 1.548 or 1.392 for change in transfers per capita (with and without state fixed effects, respectively). For interpretation purposes, this indicates that a one percentage point increase in unemployment tends to reduce transfers to the state by 3.75 million dollars or by 1.39 dollars per capita when state effects are not included. The impact increases when state and time effects are included, indicating that the impact of changing unemployment on changes in government transfers from lotteries is even greater when other differences among states over time are held constant. The coefficient on population is never statistically significant and is very close to zero. Four of the six regressions have significant F-statistics, indicating that all of the coefficients are not equal to zero, all four of these models having change in transfers as the dependent variable rather than changes in transfers per capita.

The lack of any significant results for the model using transfers per capita as a dependent variable are not necessarily surprising, especially for the state fixed effects model. Since transfers and population tend to be growing over time within states, dividing transfers by population should reduce much of the variability in the dependent variable when using panel techniques, and much of the remaining variability across states are additionally going to be attributed to the state fixed effects.

Of particular interest in this study is the lack of any measurable effect of privatization on transfers of lottery revenue as measured by the privatization dummy variable. Granted, the 
model is only able to account for one year of privatization in the state of Illinois so the results are very preliminary. However, given the supposedly superior efficiencies of private firms relative to government bureaucracies and the assumed ability to be more innovative and creative in their promotion of the lottery, one would at least expect some additional transfers of lottery dollars to the Illinois government relative to the other state governments for the 2012 fiscal year. The coefficient on the Illinois dummy is positive in all six regressions; however, the standard error is large enough to make all of the positive coefficients not statistically different from zero. This should give pause to those touting the merits of privately administered lotteries and also provide support for current and potentially future lawsuits in states like Pennsylvania and Ohio that have and will likely be filed to prevent the state from turning over lottery operations to a private company.

On the other hand, since the unemployment rate in Illinois actually increased from 2011 to 2012 from $9.0 \%$ to $9.4 \%$, and given the negative coefficient on the unemployment rate in all of the models, this indicates that things actually could have been much worse for the Illinois government in terms of transfers received from lottery sales. While the Illinois Lottery fell far short of the lofty promises made by Northstar, the actual revenues generated were slightly higher than would have been predicted given the state of the Illinois economy (although, naturally, care must be taken in place too much confidence in statistically insignificant coefficients.) Using the (non-statistically significant) point estimates on the Privatization Dummy for the 6 models tested, the Illinois Lottery in 2012 generated between \$21.2 million and \$28.9 million more than would have been predicted based on Illinois' historical experience and its economic climate during that year. Combine these potential gains with the additional $\$ 20$ million fine the state 
collected from Northstar due to the company's failure to meet its revenue projections, and a case can be made that privatization has actually been quite a positive experience for the state.

\section{Conclusion and Future Research}

State-run lotteries offer products to consumers that add to the variety of other gambling options in the United States. Growth in the lottery industry is discussed in relation to the growth of some of these other options, with a particular focus on sports gambling. As states continue to seek additional ways to increase state transfers from lottery sales, many states are considering the option of privatizing their lottery operations in order to gain from the efficiencies and innovations of a privately operated company. As demonstrated in this paper, however, states should be cautious about assuming that privately run companies can offer substantial gains in transfer dollars and they may struggle to meet their stated sales goals. While the paper is preliminary in that there is only one year and one state with a full year of privatized operations, the empirical models do indicate that economic variables such as state unemployment rates and state income provide statistically significant predictors of changes in state transfer revenues while privatization of lotteries, based on the limited available data, do not have a significant impact. As states such as Indiana and New Jersey join the ranks of states choosing to privatize their lottery operations, the data set can be expanded to include more observations for privately run state lotteries and the results offered by the expanded model will provide further conclusions on this controversial issue. 
Table 1: Summary Statistics

Variable:

Transfers (in milliions)

Transfers Per Capita

Income

Income Per Capita

Population

Unemployment Rate

Change in Transfers (in millions)

Change in Transfers Per Capita

Change in Income

Change in Income Per Capita

Change in Population

Change in Unemployment Rate

$\begin{array}{rrrr}\text { Mean } & \underline{\text { Std. Dev. }} & \underline{\text { Min }} & \underline{\text { Max }} \\ 412.87 & 482.57 & 5.72 & 3,049.15 \\ 74.21 & 81.84 & 6.62 & 375.06 \\ 260,419.80 & 291,407.30 & 19,976.50 & 1,669,594.00 \\ 38,737.31 & 7,223.57 & 25,979.79 & 73,343.84 \\ 6,635,578.00 & 7,044,558.00 & 567,136.00 & 38,041,430.00 \\ 6.34 & 2.27 & 2.79 & 13.24 \\ 11.78 & 45.16 & -161.15 & 382.77 \\ 1.11 & 8.60 & -81.38 & 53.45 \\ 9,137.51 & 16,704.94 & -38,637.00 & 95,531.00 \\ 1,152.35 & 1,274.81 & -1,950.90 & 5,253.33 \\ 55,559.35 & 93,302.61 & -273,963.00 & 581,457.00 \\ 0.38 & 1.27 & -2.37 & 4.78\end{array}$


Table 2: Regression Results

Dependent Variable:

Change in Transfers

No Fixed Effects

\begin{tabular}{|c|c|c|c|c|}
\hline Constant & $\begin{array}{l}8.357 * * \\
(3.269)\end{array}$ & $\begin{array}{l}7.964 * * \\
(3.224)\end{array}$ & $\begin{array}{l}11.684 * * \\
(5.687)\end{array}$ & $\begin{array}{l}12.458 * * * \\
(3.631)\end{array}$ \\
\hline Change in Income & $\begin{array}{l}0.0007 * * * \\
(0.0002)\end{array}$ & $\begin{array}{l}0.0006 * * * \\
(0.0002)\end{array}$ & $\begin{array}{l}0.0002 \\
(0.0002)\end{array}$ & $\begin{array}{l}0.0002 \\
(0.0002)\end{array}$ \\
\hline Change in & & & & \\
\hline Unemployment & $\begin{array}{l}-3.276 \\
(2.268)\end{array}$ & $\begin{array}{l}-3.750 * \\
(2.176)\end{array}$ & $\begin{array}{l}-6.582 * * * \\
(2.370)\end{array}$ & $\begin{array}{l}-6.615 * * * \\
(2.358)\end{array}$ \\
\hline Change in Population & $\begin{array}{l}-0.00003 \\
-0.00003\end{array}$ & & $\begin{array}{l}0.00001 \\
(0.00008)\end{array}$ & \\
\hline Privatization Dummy & $\begin{array}{l}21.267 \\
(43.826)\end{array}$ & $\begin{array}{l}22.703 \\
(43.752)\end{array}$ & $\begin{array}{l}28.92 \\
(45.869)\end{array}$ & $\begin{array}{l}28.552 \\
(45.734)\end{array}$ \\
\hline $\mathrm{N}$ & 300 & 300 & 300 & 300 \\
\hline F-statistic & $6.05 * * *$ & $7.89 * * *$ & $1.42 *$ & $1.44 * *$ \\
\hline Prob > F & 0.0001 & 0.000 & 0.0525 & 0.0463 \\
\hline $\begin{array}{r}* * * \\
* * \\
*\end{array}$ & $\begin{array}{l}\text { significant a } \\
\text { significant a } \\
\text { significant a }\end{array}$ & $\begin{array}{l}1 \% \text { level } \\
5 \% \text { level } \\
10 \% \text { level }\end{array}$ & & \\
\hline
\end{tabular}


Table 3: Regression Results

Dependent Variable:

Change in Transfers Per Capita

\begin{tabular}{|c|c|c|}
\hline Constant & $\begin{array}{l}1.983 * * \\
(0.911)\end{array}$ & $\begin{array}{l}2.077 * * \\
(0.986)\end{array}$ \\
\hline Change in Income Per & & \\
\hline Capita & -0.0003 & -0.0003 \\
\hline & $(0.0005)$ & $(0.0006)$ \\
\hline Change in Unemployment & $-1.392 * * *$ & $-1.548 * * *$ \\
\hline & $(0.534)$ & $(0.568)$ \\
\hline Privatization Dummy & 1.717 & 2.235 \\
\hline & $(8.516)$ & $(9.219)$ \\
\hline $\mathrm{N}$ & 300 & 300 \\
\hline F-statistic & $3.26 * *$ & 0.95 \\
\hline Prob $>$ F & 0.0220 & 0.5730 \\
\hline$* * *$ & significant at $1 \%$ level & \\
\hline$* *$ & significant at $5 \%$ level & \\
\hline * & significant at $10 \%$ level & \\
\hline
\end{tabular}




\section{References}

American Gaming Association. 2013. "2013 AGA Survey of Casino Entertainment.” http://www.americangaming.org.

Ashley, Terry, Yi Liu, and Semoon Chang. 1999. "Estimating Net Lottery Revenues for States," Atlantic Economic Journal 27 (2): 170-178.

Baumann, Robert and Victor A. Matheson. 2012. "Estimating economic impact using ex post econometric analysis: Cautionary tales," in Sports and Econometrics, Plácido Rodríguez, Stefan Kesenne and Jaume García, eds., (London: Edward Elgar), forthcoming.

Benjamin, Gerald. 2013. "If the New York State Constitution Bans Gambling, Why is there So Much Opportunity to Gamble in New York?" http://effectiveny.org/professorscorner/casino-gambling/if-new-york-state-constitution-bans-gambling-why-there-somuch-opp, accessed May 23, 2013.

Blalock, Garrick, David R. Just and Daniel H. Simon. 2007. "Hitting the Jackpot or Hitting the Skid: Entertainment, Poverty, and the Demand for State Lotteries," American Journal of Economics and Sociology 66 (3): 545-570.

Brinner, Roger E. and Charles T. Clotfelter. 1975. "An Economic Appraisal of State Lotteries," National Tax Journal 28 (4): 395-404.

Clotfelter, Charles T. 1979. “On the Regressivity of State-Operated Numbers Games,” National Tax Journal 32 (4): 543-548.

Clotfelter, Charles T. and Philip J. Cook. 1989. Selling Hope. (Cambridge, MA: Harvard University Press).

DeBoer, Larry. 1990. “Lotto Sales Stagnation: Product Maturity or Small Jackpots?” Growth and Change (Winter 1990): 73-77. 
Dunstan, Roger. 1997. Gambling in California, California Research Bureau, working paper CRB-97-003.

Emiston, Kelly D. 2006. “A New Perspective on Rising Nonbusiness Bankruptcy Filing Rates: Analyzing the Regional Factors," Federal Reserve Bank of Kansas City Economic Review Q2: 55-83.

Frees, Edward W. and Thomas W. Miller. 2004. "Sales Forecasting Using Longitudinal Data Models." International Journal of Forecasting 20 (1): 99-114.

Garcia, Monique. 2013. "Private Firm Running Illinois Lottery Fined \$20 Million for Falling Short on Sales," Chicago Tribune, March 18, 2013.

Humphreys, Brad and Victor Matheson. 2013. "Booms, Busts, and Gambling: Can Gaming Revenues Reduce Budget Volatility?" in Boom and Bust Again, Robert Ascah and David Ryan, eds., (Alberta, Canada: University of Alberta Press), forthcoming."

Illinois Lottery. 2010. "Camelot Illinois Public Hearing," http://www.illinoislottery.com/content/dam/ill/documents/subsections/Management/IL_L ottery_Public_Hearing_Presentation.pdf, posted September 8, 2010.

Jamestown-Yorktown Foundation, 2013. "The Virginia Company of London," http://www.historyisfun.org/pdf/Laws-at-Jamestown/VA_Company.pdf, accessed May 23, 2013.

LaMarra, Tom. 2013. "Total Handle Up for First Time Since 2006,” http://www.bloodhorse.com/horse-racing/articles/75370/total-handle-up-for-first-timesince-2006, posted Janury 5, 2013. 
Louisiana Lottery Corporation. 2013. "Lottery History,"

http://www.louisianalottery.com/index.cfm?md=pagebuilder\&tmp=home\&cpid=68, accessed May 22, 2013.

Matheson, Victor A. and Kent R. Grote. 2008. "U.S. Lotto Markets," in Handbook of Sports and Lottery Markets, Donald. B. Hausch and William. T. Ziemba, eds., (New York: North Holland), 503-524.

Mikesell, John L. 1994. “State Lottery Sales and Economic Activity,” National Tax Journal 47 (1): 165-171.

Montana Lottery. 2013. "How is Montana Sports Action Played?" http://montanalottery.com/msaFAQ, accessed May 23, 2013.

Nash, Betty Joyce. 2009. "Sport of Kings: Horse Racing in Maryland," Region Focus, Federal Reserve Bank of Richmond, Spring 2009, 37-39

National Football League vs. Delaware. 1977. United States District Court, D. of Delaware, 435 F. Supp. 1372, decided August 11, 1977.

National Indian Gaming Commission. 2012. "Gaming Revenue Reports,” http://www.nigc.gov/Gaming_Revenue_Reports.aspx, accessed May 23, 2013.

University of Nevada, Las Vegas (UNLV). 2013. "Nevada Sports Betting Totals: 1984-2012," UNLV Center for Gaming Research, http://gaming.unlv.edu/reports/NV_sportsbetting.pdf, accessed May 23, 2013. 